Occasional Paper No. 24

June 1990

Conventional Forces and Arms

Control: Technology and Strategy

in a Changing World

Conference Summary

Joseph F. Pilat

Paul C. White
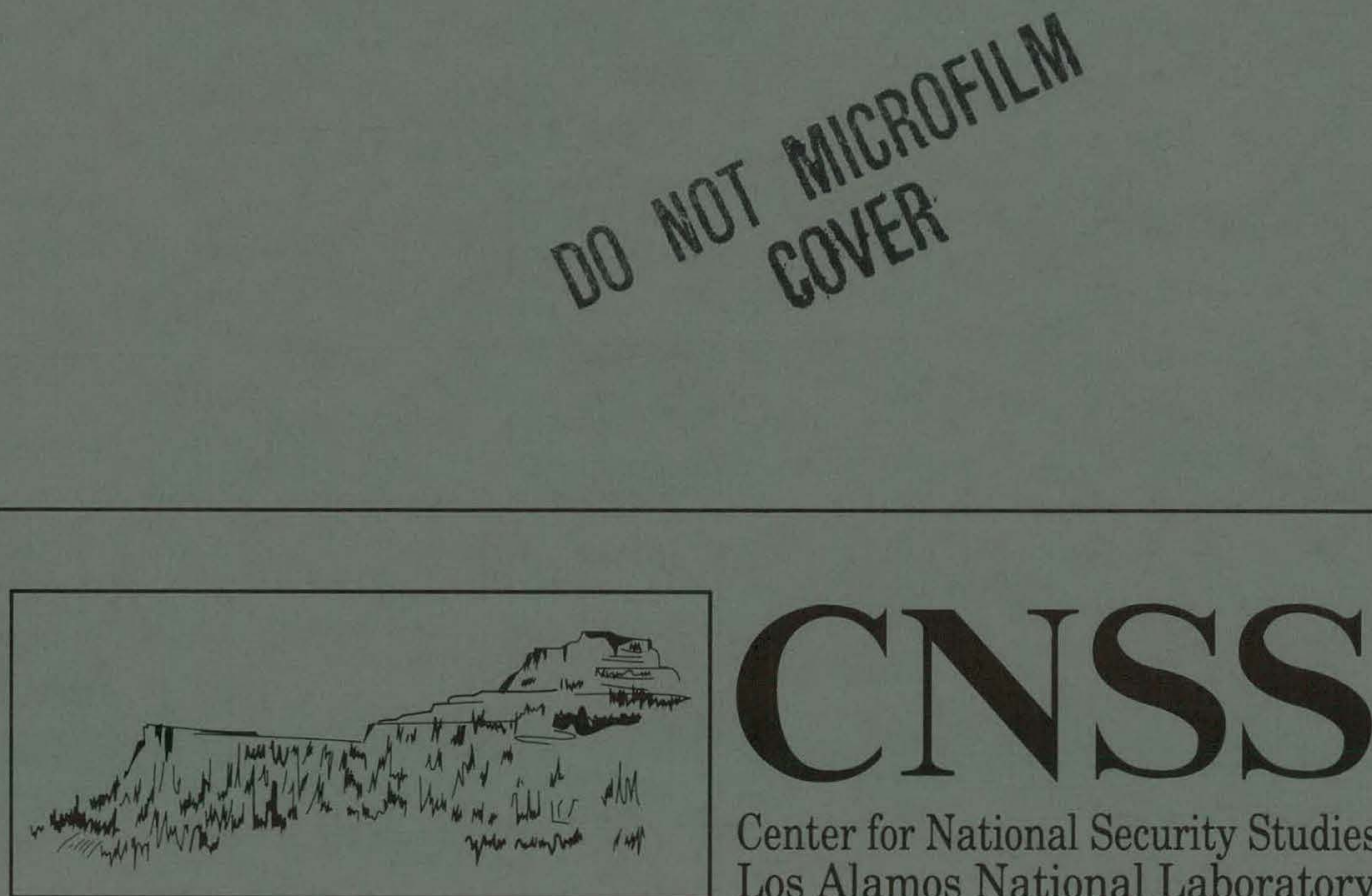

Center for National Security Studies Los Alamos National Laboratory 


\section{DISCLAIMER}

This report was prepared as an account of work sponsored by an agency of the United States Government. Neither the United States Government nor any agency Thereof, nor any of their employees, makes any warranty, express or implied, or assumes any legal liability or responsibility for the accuracy, completeness, or usefulness of any information, apparatus, product, or process disclosed, or represents that its use would not infringe privately owned rights. Reference herein to any specific commercial product, process, or service by trade name, trademark, manufacturer, or otherwise does not necessarily constitute or imply its endorsement, recommendation, or favoring by the United States Government or any agency thereof. The views and opinions of authors expressed herein do not necessarily state or reflect those of the United States Government or any agency thereof. 


\section{DISCLAIMER}

Portions of this document may be illegible in electronic image products. Images are produced from the best available original document. 


\section{CNSS OCCASIONAL PAPERS}

The following is a selection of titles in the CNSS Occasional Papers series.

No. 1. A Role for National Laboratories in Enhancing Economic Competitiveness: The Example of High-Temperature Superconductors by Siegfried S. Hecker (LA-11092MS), July 1987.

No. 2. General Purpose Force Doctrine by John J. Weltman (LA-11115-MS), August 1987.

No. 3. Energy Issues and Policies in Eastern Europe by William G. Davey (LA-1116-MS), August 1987.

No. 8. The Role of the DOE Weapons Laboratories in a Changing National Security Environment by Siegfried S. Hecker (LA-11318-MS), April 1988.

No. 9. DOE Weapons Laboratories' Contributions to the Nation's Defense Technology Base by Siegfried S. Hecker (LA-11319-MS), April 1988.

No. 10. Los Alamos Strategic Defense Research and the ABM Treaty by Reynaldo Morales and Robert E. Pendley (LA-11262-MS), April 1988.

No. 11. The Nuclear Future: Political and Social Considerations by Robert W. Tucker (LA11279-MS), June 1988.

No. 14. Lessons of Chernobyl by Bennett Ramberg (LA-11315-MS), July 1988.

No. 15. Supercomputing: An Indispensable Component of Applied Research by Warren F. Miller (LA-11392-MS), July 1988.

No. 17. Possible Roles of Tactical Nuclear Weapons in Maritime Conflict by Bernard Kauderer (LA-11552-MS), March 1989.

No. 19. Challenges to the Nonproliferation Regime into the 21 st Century: Conference Summary by Joseph F. Pilat (LA-11564-MS), May 1989.

No. 20. Postwar U.S. Conventional Military Policy: Lessons and Implications for the Seventh Era and Beyond by Maurice A. Mallin (LA-11598-MS), May 1989.

No. 21. The Degradation of Natural Resources in the Soviet Union by Molly Cernicek, Spencer R. Pearse, and Ronald L. Smith (LA-11651-MS), September 1989.

No. 22. Conference on Energy-Based Confidence Building: Energy and Environment compiled by Louis Rosen (LA-11728-C), November 1989.

No. 23. The Soviet Union: Political and Military Trends by Joseph F. Pilat and Patrick J. Garrity (LA-11750-MS), January 1990. 
Occasional Paper No. 24

LA- $-11841-M S$

June 1990

DE9 0013538

\section{Conventional Forces and Arms \\ Control: Technology and Strategy \\ in a Changing World}

Conference Summary

Joseph F. Pilat

Paul C. White

LA-11841-MS

UC-900
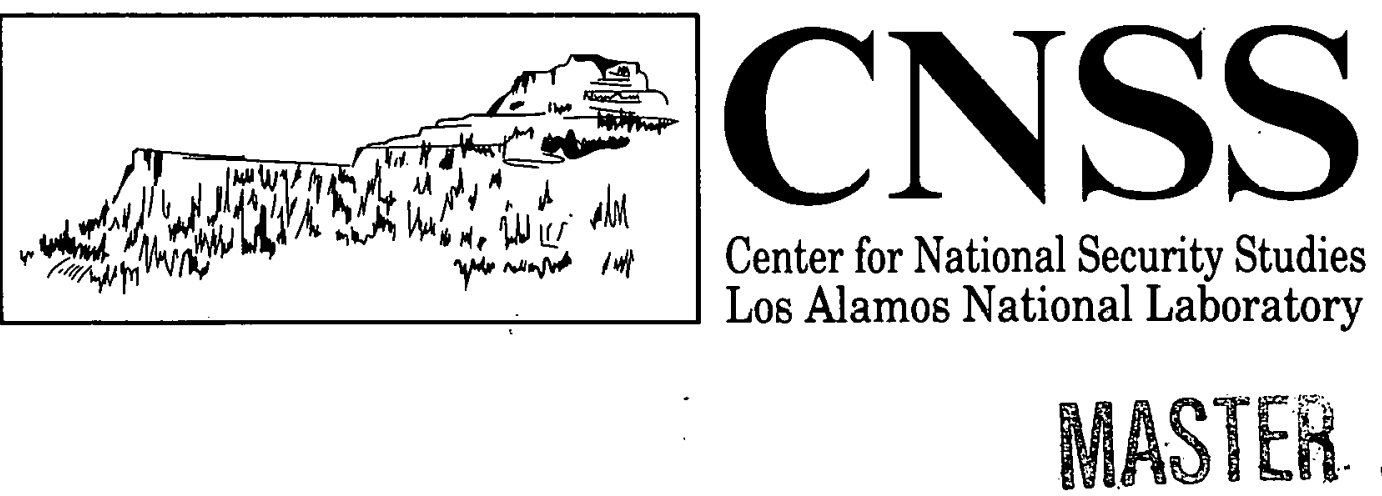
JOSEPH F. PILAT is on the staff of the Center for National Security Studies. He was a special adviser to the Department of Energy's representative at the 1985 Third Review Conference of the Parties to the Nonproliferation Treaty (NPT), and he also served as the representative of the Office of the Secretary of Defense to the first and second meetings of the preparatory committee to the 1990 NPT review conference. He has been Special Assistant to the Principal Director and Assistant for Nonproliferation Policy in the Office of the Deputy Assistant Secretary of Defense for Negotiations Policy. Pilat is serving as a representative of the Office of the Secretary of Defense at the 1990 Open Skies negotiations in Ottawa and Budapest.

PAUL C. WHITE is the Division Leader of the Applied Theoretical Physics Division at Los Alamos. He has been a Staff Member in, and Group Leader of, the Thermonuclear Applications Group, and has served as Associate Division Leader of the Applied Theoretical Physics Division. He has also been the Laboratory Program Manager for Advanced Nuclcar Wcapons Design. Before assuming his present position, he served as Deputy Director, and later as Acting Director, of the Center for National Security Studies. He was also a technical advisor to the Nuclear 'Testing Talks in Geneva.

\section{CENTER FOR NATIONAL SECURITY STUDIES}

The Center for National Security Studies is a studies and analysis organization of the Los Alamos National Laboratory. Drawing on the broad knowledge at Los Alamos of science and engineering relevant to national security issues, the Center's research focuses on the interaction between technology and policy and on developing insights that may improve the relationship between the development of new technology and the achievement of national policy goals. The Center's staff includes both resident and visiting researchers.

The Center promotes and conducts long-term research and analysis in the broad areas of defense policy and arms control. In addition, it provides insight into near-term national security policy, strategy, and technology issues in support of Laboratory management and staff. The Center also facilitates the exchange of ideas on international security issues among Laboratory personnel, government agency staffs, university faculties, and interested cilizeriss.

The Center documents its work in a number of publications. The Briefings are short, informal papers commenting on timely topics that are appropriate to the Center's areas of interest. The Occasional Papers are more extensive documents that may be monographs, seminar talks, or workshop proceedings. The Reports are formal research papers or edited conference proceedings. A book series, Issues in International Security, presents the results of the Center's research on key national and international security issues. 


\section{CONTENTS}

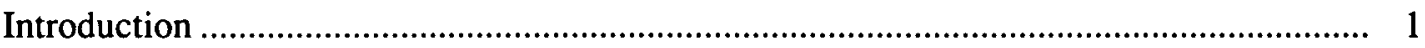

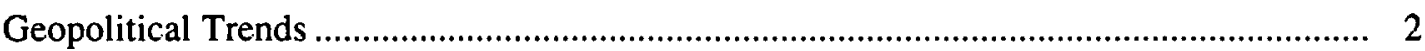

Future Military Requirements and Force Structures............................................... 3

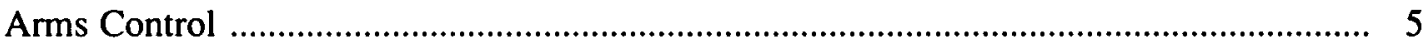

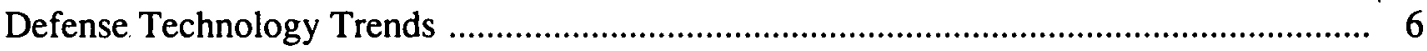

The Future of Defense Technologies ................................................................................ 8

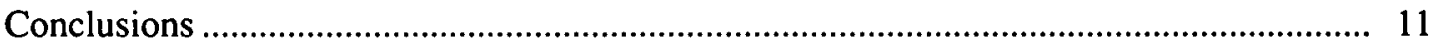




\title{
Conventional Forces and Arms Control: Technology and Strategy in a Changing World Conference Summary
}

\author{
Joseph F. Pilat \\ Paul C. White
}

\section{INTRODUCTION}

The "certainties" that have governed strategy and diplomacy in the postwar period are dissolving. Proclamations of the end of the Cold War, and even the end of history, are heard, as communism is collapsing. Eastern Europe and the Soviet Union are in turmoil. Some of the more intractable disputes in other regions of the world have been resolved or are on the path toward resolution, and despite the Chinese economic retrenchment and the repression of its democracy movement, the fortunes of democratic and market forces are on the rise. But alongside these dramatic and favorable changes, we are witnessing an acceleration of the global diffusion of political, military, and economic power; the proliferation of advanced weaponry around the world; the rise of terrorism and the drug trade; and ongoing regional conflict in certain strategic areas. Not since the late 1940s has the international security environment been so fluid, uncertain, and, despite the euphoria signaled by those who believe that history has come to an end, so unstable.

To address the implications of these changes for future roles of conventional forces and to assess the technology implications of future strategies, force requirements, and conventional arms control agreements, the Center for National Security Studies in cooperation with the Defense Research and Applications Direc- torate of the Los Alamos National Laboratory held a conference on "Conventional Forces and Arms Control: Technology and Strategy in a Changing World" at Los Alamos from September 25-27, 1989. The distinguished participants from government, industry, and academia in the United States and Western Europe addressed such issues as:

- What are the implications of geopolitical and technological trends for international security and stability?

- How will these global changes affect U.S. and allied strategies and force structure, especially the requirements for conventional, nonnuclear forces?

- What will be the role of and rationale for conventional forces in the context of current and prospective allied security requirements?

- How can the West assure it will have the forces necessary for its security?

- How will technological developments influence the structure of tomorrow's conventional forces?

- What impacts will arms reductions have on future systems and force structures?

- What are the prospects for the development and deployment in weapon systems of future conventional military technologies, in light of existing and potential political, economic, bureaucratic, and other impediments? 


\section{GEOPOLITICAL TRENDS}

The postwar period was one of extraordinary stability; geopolitics, strategy, and technology did not undergo radical change for over forty years. The period was marked by deterrence, containment, NATO-Warsaw Pact military confrontation, expansionist pressure from the Soviet Union, and non-use of nuclear weapons since 1945. However, it was suggested that history is now entering into a period of acceleration-a period during which the political order and concepts change rapidly, and significant discrepancies between strategic and technological realities occur. It may prove to be a period of super-acceleration, comparable to the period from 1932-1945 or to that of the Napoleonic wars. Unlike these earlier periods of rapid historical change, the new period is not the result of wars. The wars over the last four decades have tended to cement rather than undermine the postwar order. The Korean War, for example, furthered the East-West confrontation, the policy of containment, and the NATO military build up that have marked the postwar strategic milieu.

In many important ways, these changes represent victories for the policies and interests of the United States and the West. But some important cautions were urged. It was noted that although the Soviet threat to U.S. and Western interests continues to change over time, it still persists and we must continue to monitor the changes occurring in the Soviet Union and assess them realistically. Despite dramatic developments in the Soviet Union and Eastern Europe, Soviet military capabilities have only recently shown indications of change and remain formidable. Even if significant Soviet force reductions are achieved in the future it is by no means certain how much overall Soviet capabilities will decline if remaining forces are modernized and reorganized. Moreover, the instability in the Soviet Union and Eastern Europe could pose dangers to European security and stability. While it was noted that the revolution in the East will be the essential driving force in shaping the security environment of Europe, the reemergence of Germany in European and global affairs was also regarded as an important force in defining the structure of Europe. Dealing with the shape of a future Europe, and the role of the United States and NATO within it, will require a concerted strategy in the West. At some point, it was argued, the current security system in the West would have to be redefined.

The military threat from the East is now perceived to be diminishing, however, and the prospects for East-West arms control have rarely seemed so promising. In Furnpe major reductions beyond those contemplated by the Conventional Forces in Europe (CFE) negotiations are possible, and force reductions and restructuring may reduce or remove the capability for sudden, deep-thrusting attacks by the Soviet Union. It was expected that as a result of CFE and unilateral moves, U.S. forces stationed in Europe would be significantly reduced, but that some level of U.S. forces would remain. NATO conventional forces, with a modified doctrine, can be expected to assume the primary burden of defense and deterrence in this situation; however, many participants noted that conventional dcterrence has never been enduringly successful and that the requirement for a NATO nuclear capability will remain essential to serve as the ultimate guarantor of security. It will also be important, in this unstable period, to hedge against reversals in the Soviet Union that could presage a return to confrontational policies and new military huildups in Europe.

Although East-West tensions are subsiding, developments in other parts of the world are not necessarily favorable. The economic challenge posed by a growing Japanese economy and the prospect of an economically integrated Western Europe, the prospect of the militarization of some Pacific Rim countries, and the emergence of regional powers in the Third World could all pose fundamental challenges to U.S. interests and security in the decades ahead. The ability of the United States to respond to this emerging situation, it was argued, was complicated by the likelihood of reduced U.S. forward-based forces in the future. While these threats are real, we do not at 
present fully understand the shape of things to come-the precise nature of the threats that we will confront in the 1990s and beyond.

Preserving a high order of stability should continue to be the primary objective of U.S. policy in the Pacific Rim region. It was noted that regional conflicts remain unsettled in the Western Pacific, that China will be more likely to flex its muscles in East Asia in the future, and that there are emerging regional and subregional powers in Asia that will be playing a more active and assertive role in the future. While the United States will be challenged by the growing economic power of Japan and other Asian states, and by the prospect of their rearmament, it will be in the U.S. interest to remain engaged in the region. In northeast Asia, so long as North Korea remains a threat through its hostile policies and its military capabilities, the continued presence of U.S. forces (at reduced levels) in South Korea and U.S.-Japanese military cooperation will be necessary to deal with the threat. The presence of U.S. forces was also viewed as necessary to ensure that Soviet forces cannot become dominant in the region.

The Third World is not likely to pose a threat to U.S. survival or genuinely vital interests. However, challenges from the Third World to U.S. interests, including the use of force against U.S. interests, citizens, and military forces, are likely and could increase. The United States will have to be able to protect itself against Third World contingencies such as terrorism, hostage-taking, advanced weapon proliferation, interference with navigation on the high seas, and drug trafficking. U.S. interests also dictate the need to counterbalance any Soviet military moves or attempts at political domination, or the emergence of new hostile regional powers, in regions where the United States and the West have important interests. In the pursuit of these interests, there will be constraints against U.S. intervention, and a higher threshold for intervention was perceived as likely. In this context, a reassessment of which interests might require military action by the United States, and a resolution of the issues that have hampered efforts to shape U.S. forces to deal with the full range of requirements for low-intensity conflict, were viewed as necessary.

With the increased need for dealing with a panoply of contingencies ranging from conflict in Central Europe to terrorism in Central America, a consequence of the global changes and increasing diffusion of military, economic, and political power, it will be increasingly necessary to be able to deal with dynamic, ambiguous, and complex relationships with allies and adversaries. The manner in which we are best able to influence, deter, and divide potential adversaries will require strategic thinking.

\section{FUTURE MILITARY REQUIREMENTS AND FORCE STRUCTURES}

Despite these uncertainties and potential dangers, and barring a reversal in the process of the liberalization of the East, the perceived reduction in the Soviet threat along with competing budgetary priorities and prospects for the negotiation of deep cuts in nuclear, chemi$\mathrm{cal}$, and conventional arms in the near future make reductions in Western military forces and defense spending certain in the decade ahead. In this situation, there is a pressing need to develop new strategies and force structures to ensure that the security and interests of the United States and the West are protected against existing and emerging regional and global challenges. Yet, the uncertainties we confront make this requirement very difficult. To some extent, forces are always designed without a perfect definition of national security objectives and strategy. Force structure, along with strategy, national security objectives, and requirements for military $R \& D$, have traditionally been driven by threat forecasts; always imprecise and a source of uncertainty, these predictions of the future are far more difficult in a time of dramatic change. Yet, as we reflect on the emerging world, and the positive and negative dimensions it is now revealing, not all that we confront is new. Although Soviet military influence is waning, and the Soviet threat is perceived to be diminishing, a threat remains. 
The focus on forces capable of fighting a high-intensity conflict in Europe against the Warsaw Pact, with the assumption that these forces would be adequate for lesser conflicts, is changing. This focus was dictated by the threat, and the requirement for these capabilities will remain in one form or another so long as Soviet capabilities continue to pose a threat to Western security. However, the contingencies we will face outside of Europe will undoubtedly be more demanding in the future than in the past.

In response to these changes, given the emerging threat environment, and the prospect of reduced forward basing, the need for multicapable forces with global reach appears critical. We can thus anticipate a future requirement for more flexible and mobile forces, and greater strategic lift capabilities, whatever the precise nature of new threats in the next decades. While such flexible forces are a necessity, it is by no means clear how one can achieve the flexibility that would allow reduced forces to continue to meet the demands of high-, medium- and low-intensity conflict, in a world in which the military requirements established in the early post-war years have not entirely vanished but the focus on East-West conflict is increasingly being broadened to deal with insurgencies and counter-insurgencies, terrorism, and the drug war. 'I 'he question of generalized versus specialized forces will also have to be addressed in force planning, along with the question of how to reconfigure our forces in a world where 50 percent cuts in conventional as well as nuclear forces are a distinct possibility.

There will be reductions in force structure and manpower, whatever happens in the arms cuntrol arena. Major challenges for torce planning will emerge from the changing intemational security environment. Reserve components will become more important and it will be necessary to make them more effective. Logistics support will have to be improved, and technology can play a role. Improved command and control is essential; both technology and operational doctrine can contribute to moving important elements of information more rapidly around the battlefield to improve the effectiveness of reduced forces. Increased military integration with our allies is required, and a special effort is necessary to enhance complimentary rather than duplicative efforts. Mobility is a challenge; it is not addressed merely by purchasing more sea-lift and air-lift capability, but by ensuring that the forces themselves are more mobile and capable of being moved. The human area, and human-weapon interface requires further study, as does the role of space in conventional conflict. To address such issues in a rational manner, there is a continued requirement for dialogue between those in the military and Pentagon policy positions with a responsibility for developing strategy to assure that forces are structured in a manner that best allows them to be responsive to the military requirements derived from national security objectives and strategy.

Many participants noted that any changes in force structure should assume a continuing U.S. presence and influence in the world. At a time of rapid change and growing interdependencies, it was viewed as irrational to retreat from the world, despite the attachment of many American intellectuals to isolationism. And, unless we totally disengage from the world, the alliances we established in the postwar period will remain essential to U.S. security not only to deal with the residual Soviet threat, or the prospect of its reemergence, but to manage better the changes occurring in a manner consistent with Western interests.

United States influence in the world will be limited if we act alone; therefore, we should continue working in cooperation with our allies on matters of strategy, technology, doctrine, and operations. As U.S. force levels decline, current force structures will require changes if they are to be responsive to the changing international security environment and to emerging political, economic, diplomatic, and military challenges. The issuc of how the members of NATO will contribute to Western security is paramount. The "layer cake" approach to NATO defense with national corps stationed shoulder to shoulder across the length of the inter-German border 
may be altered as a result of changes in the status of Germany and by internal and external pressures for bringing home U.S. and other NATO forces. A possibility is to enhance interdependence. Over time, the U.S. role in NATO defense may increasingly focus on the unique contributions it can offer with its nuclear forces, intelligence, command and control, communication, information processing, and the like. Similar challenges confront us in Asia and the rest of the world with regard to the changing roles and specialization of forces at the medium and lower ends of the spectrum of warfare.

As a result of these considerations, there will be military pressures to maximize U.S. leverage and influence in NATO with U.S. forces, albeit at lower levels and perhaps with a different force structure designed to preserve U.S. engagement in a time of dramatic change. Uncertainties are also great on the Pacific Rim, and continued U.S. military engagement is essential. However, here too force structure and doctrine will require modification to be responsive to the changes that are occurring. Questions remain conceming U.S. and alliance strategies, including extended deterrence, flexible response, and other issues.

\section{ARMS CONTROL}

Arms control was viewed by some participants as a means of dealing with current uncertainties-as a means of regulating change and making desired changes irreversible. In this sense, conventional arms control is a conservative force in the diplomatic arena, operating within the framework of the postwar East-West confrontation, a framework that appears to many to be increasingly irrelevant or unacceptable. While this was seen to be a reasonable role, it means that arms control is reacting to rather than initiating or guiding the changes in the world we are now witnessing, and that arms control is unlikely significantly to affect these changes. Arms control will be a factor in determining future force requirements, but it is unlikely to be a dominant factor.
Conventional arms control can, however, to some degree improve the predictability of the current situation, and alleviate public opinion problems in the West in light of Gorbachev's initiatives. The current CFE talks, while they do not envisage radical changes in NATO forces or American forward deployed forces, were seen to be useful in alleviating certain of NATO's real or perceived problems, especially a sudden, unreinforced standing start attack by Soviet forces, and thereby increasing stability. They do not genuinely deal with the problem of attack following mobilization, perhaps a more credible scenario. Whatever the probability of a standing start attack, especially since the dramatic changes occurring in Eastern Europe and demands for the removal of Soviet forces in Hungary and Czechoslovakia, it may be useful, in a time of instability, to have changes formalized in an arms control agreement. Moreover, confidence- and securitybuilding measures, and other forms of socalled operational arms control, could, it was suggested, assist verification and provide a means of assessing the fluid situation and determining whether measures to redress an increasingly unacceptable situation are necessary. In this sense, such measures could increase actionable warning time.

It was noted that parity, which CFE seeks to achieve, does not equal stability. The removal of Soviet troops from Eastern Europe which is now underway independent of the CFE negotiations will be one of the most important contributions to stability; to the extent that CFE can contribute to the goal of stability, it will depend upon the force levels at which parity is achieved in CFE and possible followon negotiations, as well as on efforts made to ensure equal capabilities and sufficient warning time. Deeper cuts than those contemplated in the first phase of CFE raise issues of force planning, readiness, and mobilization, and it is by no means clear that deeper cuts by themselves resolve the problem of a reinforced attack. There is also the option of unilateral or reciprocal reductions, which may be preferable to a treaty.

While arms control could be beneficial, however, continuing alliance differences over 
CFE reflect different perspectives and interests on security and have been difficult to address. Arms control can damage alliance solidarity and, if it undermines the alliance, any benefits would not be worth the costs. Moreover, arms control agreements frequently create a reluctance in the West to develop certain weapon systems even if they are not prohibited by a treaty. Specifically, arms control threatens to limit or eliminate technological options, either by providing for limits on modernization and the introduction of futuristic technologies; by foreclosing them inadvertently through agreed limits on platforms or other controls; or by making such advances politically unpalatable by establishing a climate within which the introduction of new technologies would be seen as destabilizing or as undercutting agreements. On the contrary, the United States should avoid compromising technology options in the arms control process, and, perhaps, insist on increased R\&D budgets as the price for an arms control agreement, because the anticipated reductions in force levels will make technological leverage increasingly important in meeting future U.S. global security requirements. The cuts contemplated in the CFE negotiations, it was noted, will not provide significant economic benefits. It was suggested that the costs of pulling troops back, demobllizing those troops, and the like, would be significant. Arms control may not be focusing on the right problems, such as future force structures. Moreover, it may not, as in the INF case, be possible to agree on a regional, European scope for conventional arms control. Eventually, it was suggested, Asia may have to be brought into the equation and conventional arms control be considered in a global context. In any event, wlth even deeper reductions in conventional forces, it was suggested that the contingencies we may face are likely to be more unpredictable than those in the past, and it will be important to reexamine NATO strategy under these conditions. In this situation, the problem of competitive mobilization and competitive rearmament must be addressed. In addressing such problems, many participants viewed emerging technologies as offering a potentially important contribution.

\section{DEFENSE TECHNOLOGY TRENDS}

On the basis of technology trends and forecasts some observers foresee a world where advances in lethality and real-time reconnaissance and surveillance will revolutionize the battlefield of the future and where the large conventional land armies and the element of surprise, which have long dominated warfare, will be displaced. Should this world materialize, large weapon platforms and perhaps even manned platforms will become far less important, and autonomous, long-range standoff weapons will become increasingly important, as will continuous, all-weather surveillance and reconnaissance.

Such a world would emerge only after several decades of struggle between competing technologies-measures and countermeasures. For example, increased warning times, and the associated reduced likelihood of surprise, would result from the development of improved reconnaissance and surveillance systems. These systems would exploit emerging technologies, including multimode sensors that integrate the information gleaned from target emanations across broad spectral ranges and different energy types, such as acoustic, thermal, optical, and other electromagnetic bands. Prompt, automated target identification would be accomplished by high-speed, real-time processing of these data, using expert systems and new mathematical analysis techniques operating on microelectronic neural networks, or perhaps on integrated optical circuits. Combinations of ground-based, space-based, and remote-controlled or autonomous airborne sensor platforms offer the promise of continuous, allweather coverage of selected regions and would be rapidly deployable to other regions in times of crisis. Since camouflage techniques, such as stealth, tend to mask only part of a target's signature, it may be that integrated, broadcoverage sensors will prevail in the technical competition between surveillance, on the one hand, and deception and cover, on the other.

These same technologies could be employed in the development of smart or even brilliant weapons, capable of real-time target acquisition and very high kill probability per round. 
Improved signal processing and multichannel communication networks will enable better, more mobile, and more rapidly responsive command and control. This will, in turn, enable more flexible and more survivable operational capability. Large forces could thus be engaged simultaneously, rather than sequentially, and in depth across a broad front. Advantages once associated with mass would then eventually fade along with those of surprise.

The emergence of very high weapon lethality will create pressure for unmanned, rather than manned, weapon platforms. Autonomous, longrange standoff weapons will become increasingly important. Options will exist to defend, or to attack, high-value targets using tactical directed-energy weapons (DEW) or kineticenergy weapons (KEW), Counter-sensor or counter-communications weapons will employ explosive optical munitions or high-power microwaves. These and other new technologies would make the battlefield of the twentyfirst century very different from that of today.

At present, however, this sort of forecast only indicates what might be possible. The West has a decisive lead in all of the technologies that are vital to developing these military systems. But this suite of technical capabilities is also being pursued by the Soviet Union, and it can be anticipated that many of these capabilities will be disseminated to or developed in the Third World by the twenty-first century. Although the Soviets have begun the process of reducing weapons and converting certain military resources to civilian use, they also appear committed to modernizing their formidable ground forces, navy, and strategic nuclear forces. The prospects for technological innovation are great, and the Soviets anticipate a technological revolution in military affairs, based on advanced conventional weapons, comparable to the introduction of nuclear weapons.

In the Third World, we are already witnessing the dissemination of some of the most advanced conventional military capabilities, including M-1 Abrams main battle tanks, F-16 fighters, Exocet anti-ship missiles, and SS-21 surface-to-surface missiles; we are also wit- nessing the spread of advanced conventional submarines, and nuclear submarine programs; growing space-launch, satellite, and ballistic missile capabilities; and increasing programs and capabilities to develop chemical, biological, and nuclear weapons. We can anticipate that such capabilities, and perhaps even more advanced capabilities, will be developed and deployed widely in the twenty-first century, fundamentally changing the manner in which we address Third World contingencies.

Given this new dimension of the Third World threat, the high-tech and the low-tech responses we have attempted in the past, which have had only limited success, will no longer be adequate. Low-technology solutions can be found for dealing with many problems posed by lowintensity conflict (LIC), and where available should be used. However, low-tech solutions are frequently inadequate for dealing with adversaries armed with advanced weaponry. In such cases, rather than eschew high-technology altogether, or utilize systems designed for other missions and theaters of operation, it is essential that we maximize our technological advantages in specific LIC environments, if we are to be able to respond effectively at all in the future. Many of the technologies being developed for the SDI, advanced conventional weapon and arms control verification programs, could be adapted for LIC applications. A commitment by the U.S. to use, where appropriate, advanced technologies in low-intensity conflict situations would require a fundamental change in thinking. When advanced technologies have been utilized in LIC situations, the results have not always been those anticipated, e.g. the Aegis system and its role in the Iranian Airbus disaster. Moreover, we have frequently been reluctant to deploy technologies developed to counter the Soviet threat, in the fear that they might be compromised if they were used in Third World conflicts where the Soviets might monitor the results of their use or obtain access to them and either adapt them for their own use or seek countermeasures. Finally, we have not thought systemmatically about the application of these technologies in LIC and, as a consequence, we have not thoroughly identi- 
fied requirements and promising technologies, and we have not adequately funded R\&D in appropriate areas. However, we may no longer have a choice; the proliferation of such capabilities as SAMs, Stingers, and Exocet missiles in areas of interest to ourselves and our allies require high technology choices. In response, high technology options will be critical.

To some extent, the revolutionary possibilities inherent in the proliferation of the defense technologies that now exist or are anticipated by the beginning of the next century enhance the uncertainty and instability of the current security milieu but. more importantly, they offer the U.S. the means to address the challenges derived from the period of dramatic changes we are witnessing. In this context, it was noted that strategy should guide the choice of new conventional force technologies; however, the need for technological possibilities, both favorable and unfavorable, to exert a strong influence on the choice of strategy in a rapidly changing world was also highlighted.

Two clear lessons emerged. First, if we believe that we are on the threshold of a military technological revolution, and that an EastWest conflict in the next ten years is highly unlikely, then it was argued that a greater emphasis should be placed on R\&D and modernization than on maintaining current active force levels. And second, despite anticipated deep cuts in forces, both nuclear and conventional, resulting from East-West arms control efforts, we cannot expect a world in which the traditional Western reliance on technology diminishes. Indeed, Western reliance on advanced technologies in the emerging threat environment will remain necessary precisely because of anticipated Soviet moves toward a high-technology military and because of the continued proliferation of high-technology capabilities in the Third World. There are serious obstacles to our capability to retain our technological edge and apply emerging technologies to these military missions, however, and it is by no means certain that available and emerging technologies will be exploited by the West in the future.

\section{THE FUTURE OF DEFENSE TECH- NOLOGIES}

Throughout the course of the twentieth century, the militaries of the West and especially the United States have driven the development of new technologies through procurements and R\&D programs, from aviation to nuclear energy, computers, integrated circuits, and composite materials. These technologies in turn have strongly influenced the shape of the military forces as well as that of the civil economies of the West and the world. These militarilydriven technologies have furthered Western competitiveness, and enhanced Western security.

However, the technological landscape is changing. The civil sector has increasingly been leading the military in the development of new, critical technologies, and many advances are coming from Japan and Western Europe who devote a greater share of governmental R\&D funding to programs designed for the civil sector than does the United States. Moreover, defense technology has been evolving only slowly in recent decades, in contrast to the revolutionary changes of four decades ago. And despite high military expenditures in recent years, high technology military systems are being developed and deployed slowly, that is, the rate of technological innovation is outstripping the integration of technologies into currently deployed systems. At the present time, currently deplnyed systems may use $1970 \mathrm{~s}$ technologies; forty years ago, the employment of twenty-year-old technologies would have relegated systems to obsolesence. There is currently a great disparity between the technologies that are commercially or otherwise available and those that have been exploited fully in military systems. This state of affairs is no doubt attributable, to some extent, to the revolutionary weapons advances of the 1940s and 1950s and the stable international climate that has persisted since. The premium has been on evolution rather than revolution in deployed forces as it was in strategy and diplomacy.

Despite the problems we confront with the integration of new technologies into military 
systems, as we address a new strategic milieu, we must have an understanding of technologies that can have a revolutionary impact on conventional forces and conventional warfare. Among such technologies, as suggested above, are conventional strategic weapons and new, more lethal conventional warheads, as well as technologies that can influence extended, largescale conventional warfare, information warfare, and counter-mobility operations. The Soviet Union and even countries in the Third World have shown interest in these technological possibilities, despite the changes we are witnessing in the world, suggesting that the competition in military technology will continue. Increasing our emphasis on R\&D and developing a suite of technological options that are responsive to the full range of possible future military contingencies could, in principle, address current geopolitical uncertainties and provide technical hedges for national security, strategy, and force structure. However, there are serious political, economic, bureaucratic, and technological obstacles to achieving this level of responsiveness.

Politically, the prospect for a fundamental improvement in East-West relations already appears to have diminished perceptions of the need for increased or even level defense spending. Reductions in the defense budget appear inevitable and major force reductions, unilateral and negotiated, are being contemplated. In this environment, R\&D funding must be protected, but we need to ensure that $R \& D$ spending is devoted to technologies that will genuinely make a difference in the future in a time of uncertainty about what the forces and contingencies of the future will look like. These technologies need not be revolutionary; however, they must increase military effectiveness dramatically.

In this climate of uncertainty and change, there may be reason not to commit ourselves to the procurement of new systems which may not be optimal, or even usable, in meeting future military requirements. Yet, there is an equally grave danger of being wholly unprepared for future contingencies. In these uncertain times, and amid the fluid security environ- ment with which we are faced, prudence dictates the need to shift emphasis from "deployed" to "deployable" forces, which entails an R\&D program designed to provide a suite of rapidly produceable and deployable weapons systems should requirements for them emerge.

Given the problems the United States has encountered with inadequate testing of weapons systems, along with increased budgetary constraints on developing, testing, and exercising complex military systems, and with environmental and arms control concerns, there will be a growing reliance on computer simulation for system development, testing, and evaluation. "Virtual prototyping" is especially promising. It involves a computer-generated (virtual) environment in which material and system prototypes can be developed and tested by the military, providing a cost-effective approach to evaluating multiple options, the possibility of early training and doctrine development, and an option to deal with unstable, or crisis, situations at the same time (real time) as they develop. Increased emphasis will need to be placed on the development of subsystems that can be combined as needed to form integrated systems for different applications. Additionally, hardware development must be coordinated with the simultaneous development of the required manufacturing capability. Investment in such approaches, which trades off current military capabilities for future opportunities may be necessary. For this approach to be successful, the capability for defense industrial mobilization, a capability that has atrophied, needs to be restored to enable the mass production of weapon systems in response to the emergence or clarification of concrete threats in the future.

Funding for defense $R \& D$, both government and industry, has been uneven and is projected to decline significantly in the decade ahead, as the defense budget declines and government actions have reduced industry resources devoted to R\&D. Moreover, cost control, competition, risk-aversion and a focus on the evolution of existing product lines have all eroded U.S. defense industry's commitment to technology-base research and development. The 
defense industry, confronted by the declining military market, is already looking at diversification into commercial and high-growth military spheres, joint ventures with foreign firms, and other options, even thought the full impact of the market changes has not yet been felt. Greater funding out of constrained defense budgets will need to go to developing a viable set of technology options. Weapon costs are rising, and there is a competition for constrained resources. The expense of modern technologies has made it more difficult to maintain a wide range of options, because a decision to fund one set of technologies is done. only at the expense of others.

In an era of limited resources, then, we will have to understand how to choose among technologies. We have to increase and change our research investment, and we must change our focus to be able more rapidly to develop deployable systems and subsystems, and to incorporate technological changes into existing military systems to improve effectiveness. To do so, we will have to deal with the cost issue; we will not have major high technologies available for defense unless we understand how to produce them affordably. This problem will have to be addressed not only by those who undertake research and development, but by those who have established the rules and institutional barriers that have exacerbated the problem. Moreover, advanced technology does not necessarily cost more. For example, in the field of computing and data processing, increased speed and reliability has been achieved without an accompanying increase in cost. Similar possibilities certainly exist for the development of future defense capability.

It will also be important to address inefficlencies in lle way we spend limited resources to accomplish our goals. Technology has the potential to produce revolutionary changes; the challenge is to choose the $R \& D$ today that will create revolutionary change tomorrow. We cannot afford to acquire all technologies.

Efforts are emerging to improve our strategy for selecting which military technologies to invest in. Bureaucratically, military R\&D is affected by the development of critical technol- ogy lists by the Pentagon and others, but to date these have been flawed to the extent that they are largely generated in response to the problems of the past and the present. They do not sufficiently address the problems of tomorrow and define the critical technologies for future U.S. and Western security. There may be a set of technologies that cross cut many of the critical technologies in the Department of Defense's (DoD's) Critical Technology Plan. These technologies, which include supercomputing, superconductivity, and materials processing and synthesis, are strategic in nature and must be addressed in the coming decades for military and civil uses. A critical element of military planning in the future will be the development of a viable long-term R\&D strategy that coherently addresses objectives, funding and management for the development of technology.

The military establishment itself needs to be more proactive in identifying the new challenges confronting the United States and identifying and promoting the most promising new technological possibilities. It was observed that the record of the past demonstratcs that this responsiveness will not emerge from below; it has to come from the top.

Unfortunately, the emerging adversarial relationship between the Congress, the defense industry, and DoD has affected the prospects for a robust $R \& D$ effort. The defense establishment and service rivalries have slowed technoIngical innovation, and service bureaucracies along with Congress have frequently attempted to preserve current force strength and force structure at the expense of military R\&D at a time of declining budgets. Pentagon planners must deal with trade-offs between preserving current force levels and supporting R\&D. The Pentagon and Congress have historically agreed in seeking to preserve critical areas of the defense industrial base, including defense laboratories and production facilities. The rationale was based on political as well as security considerations. There has, however, been a reduction of defense contractors and the consolidation of the defense industry can be expected to continue. The problem confronting 
the United States is how to restructure the defense industrial base during this process, and to preserve vital capabilities and expertise.

The budget cycle is also damaging to rational planning for military $R \& D$, and the Department of Defense has been supportive of a twoyear budget as an initial step. The increased focus on cost rather than performance as the primary criterion of weapons systems has been recognized to further distort the planning process for R\&D, as both the perception (and the actuality) of the high costs of high-technology military systems (for example, the B-2 bomber and the SSN-21 submarine) make them vulnerable in military, administration, and congressional circles. And the acquisition process, in which it can take twenty years or more for a major weapon system to move from R\&D to deployment not only increases costs, but also limits the effectiveness of technological innovation and, consequently, could undermine support for R\&D. The Packard Commission noted that our inability to field weapons systems as rapidly as the Soviet Union and even some Third World countries is due in part to a cumbersome and unstable acquisition process.

And, even technological factors offset the prospects of maintaining a robust military $R \& D$ effort. Increasingly, as suggested, civil technologies are driving military technology, rather than the reverse; while offering savings, dualuse technologies raise issues of technical dependence and technology transfer. In other words, we may berome dependent on another country or countries for key components of military systems, or confronted with the question of exporting such technologies, be faced with making them widely available in international commerce, both to friends and potential foes. Such issues frequently lead to the erection of legal, administrative and other barriers to the rapid exploitation by the military of these technologies in the civil area. These civil technologies are generally also available to adversaries. With the globalization of high technology capabilities, the penetration of the U.S. industrial defense technology base by imports, the increasingly significant issue of foreign ownership, and the loss of U.S. techno- logical leadership in many areas, the prospect of technological dependence and a serious challenge to the U.S. control of high-leverage technology breakthroughs has resulted.

U.S. technological leadership, it was noted, is being widely debated. An issue today is whether, or to what extent, governmental science and technology policy should continue its focus on military $R \& D$ or shift to greater emphasis on civilian and dual-use technology. To the extent that economic competitiveness comes to define a critical aspect of U.S. national security in the 1990s and beyond, the efficiency of support for military R\&D in terms of its civil benefits will have to be reassessed.

In light of increasing technological innovation in the civilian sector of the economy and the growing importance of dual-use technologies in the military sphere, the relative emphasis of U.S. policy must be addressed if a viable governmental R\&D strategy designed to maintain U.S. leadership in critical technologies is to be developed and implemented. We must find better ways to identify and adapt civil technology to military systems, and to fund military technologies that will not be developed in the civil sector. Government labs are now engaged in the process of making the capabilities of certain technologies they have developed available to the civil sector through technology transfer and collaboration with industry. This process could contribute significantly to promoting both security and economic competitiveness. However, because no nation will dominate the full range of militarity-relevant technologies in the future, the United States must be able also to exploit technologies developed outside its borders. Rationally planned, selective cooperation with allies across the Atlantic and Pacific involving R\&D in dual-use technologies may also be promising, although it is not without problems.

\section{CONCLUSIONS}

The current changes in the international security environment are more profound than aniy since the late 1940s. History has not 
ended; in Europe it is being revived, and throughout the world it is accelerating. While the emerging world is perplexing, offering both great opportunities and grave dangers, the emerging strategic landscape is not terra incognita. The East-West confrontation of the postwar era is waning, and the prospect of conflict in Europe between NATO and the Warsaw Pact is perhaps lower than at any time in the last 45 years. Arms control agreements, including CFE, will be easier to achieve but also less significant in this environment. Despite these changes, the United States and the West will be required to meet the challenge posed by Soviet military capabilities for the foreseeable future. Furthermore, emerging political, economic, diplomatic, and military challenges, which derive from developments such as the global diffusion of power, the proliferation of advanced weaponry, and the rise of terrorism and the drug trade, will become more demanding and cannot be ignored in the future. From the global information revolution that is fueling democratic movements around the world, to the dissemination of advanced weapons that is changing the face of regional and international security, technology has been a driving and defining force in the process of change. Indeed, technology, long one of the foundations of Western economic dominance and Western security, offers the hope of addressing the uncertainties and dangers of the emerging world within current budgetary and other constraints.

Technology is only an instrument, howeverit is a means, not an end. Technology can serve national security only if it can be integrated into strategies and a force structure that are themselves grounded in reasonable threat assessments, and if it is not constrained by arms control. In the current threat environment, characterized by uncertainty and flux, it is essential that a range of technological options be developed. This requires a viable strategy for military $R \& D$ and the requisite resources for maintaining and strengthening a robust and responsive defense technology base and improving defense industrial mobilization capabilities. To implement such a strategy successfully, it will be necessary to break through a series of domestic political, bureaucratic, economic, and technological constraints that have slowed the U.S. ability to integrate new technologies into deployed weapon systems and driven spiralling weapon costs, while undermining R\&D.

Moreover, given the globalization of technology, the increasing importance of the commercial sector in technological innovation, and the growing significance of dual-use technologies for the military, the preservation of U.S. interests will require a significant measure of interdependence. Rather than rapid force withdrawals and a race toward burden shedding (as opposed to burden sharing), the dehate within NATO and between the United States and its East Asian allies should revolve around rationalizing the contributions of all allies to Western defense on the basis of what each can best contribute. The United States, for the foreseeable fulure, can best contribute to Western security through the fruits of a renewed commitment to technological leadership. 


\section{ABSTRACT}

A summary is presented of a conference that addressed the implications of changes for future roles of conventional forces and the technological implications of future strategies, force requirements, and conventional arms control agreements. The conference, held at Los Alamos September 25-27, 1989, was sponsored by the Center for National Security Studies in cooperation with the Defense Research and Applications Directorate of the Los Alamos National Laboratory.

\section{DISCLAIMER}

This report was prepared as an account of work sponsored by an agency of the United States Government. Neither the United States Government nor any agency thereof, nor any of their employees, makes any warranty, express or implied, or assumes any legal liability or responsibility for the accuracy, completeness, or usefulness of any information, apparatus, product, or process disclosed, or represents that its use would not infringe privately owned rights. Reference herein to any specific commercial product, process, or service by trade name, trademark, manufacturer, or otherwise, does not necessarily constitute or imply its endorsement, recommendation, or favoring by the United States Government or any agency thereof. The views and opinions of authors expressed herein do not necessarily state or reflect those of the United States Government or any agency thereof.

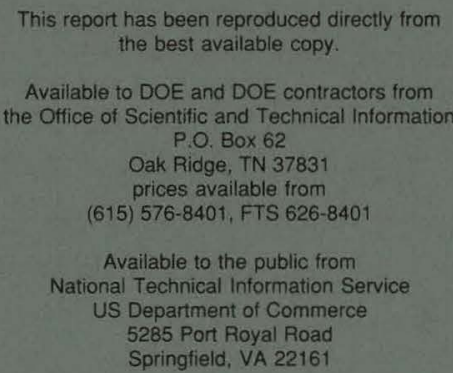

Available to the public from

National Technical Information Service

US Department of Commerce

5285 Port Royal Road

Springfield, VA 22161

Microfiche (A01)

\begin{tabular}{|c|c|c|c|c|c|c|c|}
\hline Page Range & $\begin{array}{l}\text { NTIS } \\
\text { Price Code }\end{array}$ & Page Range & $\begin{array}{l}\text { NTIS } \\
\text { Price Code }\end{array}$ & Page Range & $\begin{array}{l}\text { NTIS } \\
\text { Price Code }\end{array}$ & Page Range & $\begin{array}{l}\text { NTIS } \\
\text { Price Code }\end{array}$ \\
\hline $001-025$ & $\mathrm{~A} 02$ & $151-175$ & $\mathrm{~A} 08$ & $301-325$ & A14 & $451-475$ & A20 \\
\hline $026-050$ & $\mathrm{AO3}$ & $176-200$ & A09 & $326-350$ & A15 & $476-500$ & A21 \\
\hline $051-075$ & $\mathrm{AO} 4$ & $201-225$ & A10 & 351.375 & A 16 & $501-525$ & A22 \\
\hline $076-100$ & A05 & $226-250$ & A11 & 376.400 & $A 17$ & $526-550$ & A23 \\
\hline $101-125$ & A06 & $251-275$ & $A 12$ & $401-425$ & A18 & $551-575$ & A24 \\
\hline $126-150$ & $A 07$ & $276-300$ & $A 13$ & $426-450$ & A 19 & $576-600$ & A25 \\
\hline & & & & & & 601-up" & A99 \\
\hline
\end{tabular}


